Bond University

Research Repository

\title{
The novel use of LEGOß-based therapy to develop communicative competence in children who use augmentative and alternative communication (AAC) systems
}

Gough, Suzanne; Dutton, Nicola

DOI:

10.1136/bmjstel-2018-aspihconf.15

Licence:

CC BY-NC-ND

Link to output in Bond University research repository.

Recommended citation(APA):

Gough, S., \& Dutton, N. (2018). The novel use of LEGO®-based therapy to develop communicative competence in children who use augmentative and alternative communication (AAC) systems. The 9th Annual Conference of Association for Simulated Practice in Healthcare, Liverpool, United Kingdom. https://doi.org/10.1136/bmjstel2018-aspihconf.15

\section{General rights}

Copyright and moral rights for the publications made accessible in the public portal are retained by the authors and/or other copyright owners and it is a condition of accessing publications that users recognise and abide by the legal requirements associated with these rights.

For more information, or if you believe that this document breaches copyright, please contact the Bond University research repository coordinator. 


\section{The novel use of LEGO $^{\circledR}$-based therapy to develop communicative competence in children who use augmentative and alternative communication (AAC) systems.}

Nicola Dutton

Lansbury Bridge School \& Sports College
Dr Suzanne Gough

Manchester Metropolitan University
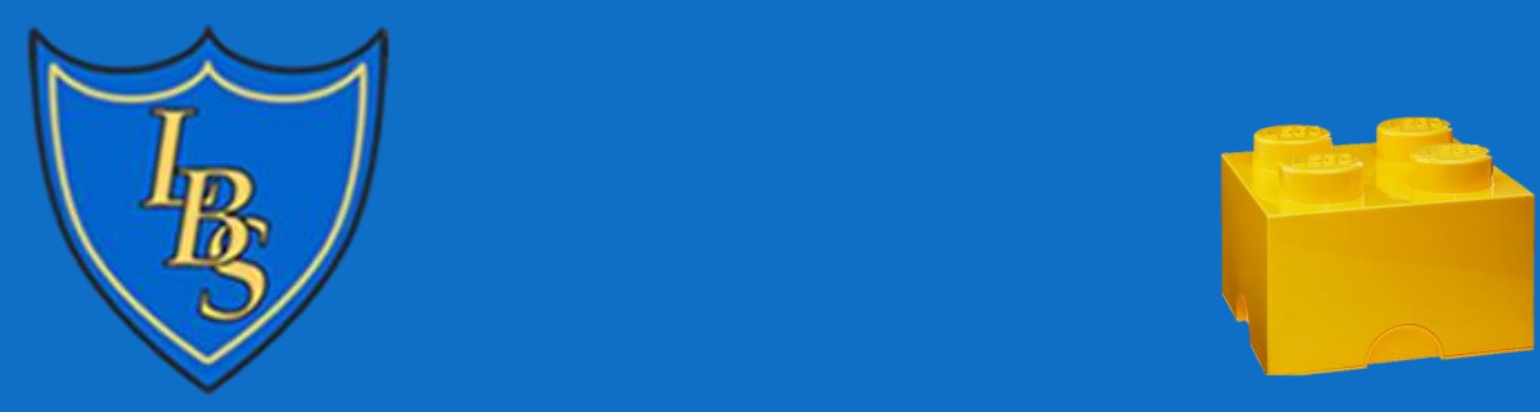


\section{Lansbury Bridge School \& Sports College}

A specialist educational provision catering for pupils aged 3-16 years who have Educational Health and Care Plans reflecting their complex learning and/or medical needs

Most pupils have communication challenges which staff and pupils work together to overcome, and strengths that we celebrate

The achievement of effective overall communication skills can be complex and challenging for our pupils that use Augmentative and Alternative Communication systems (AAC)
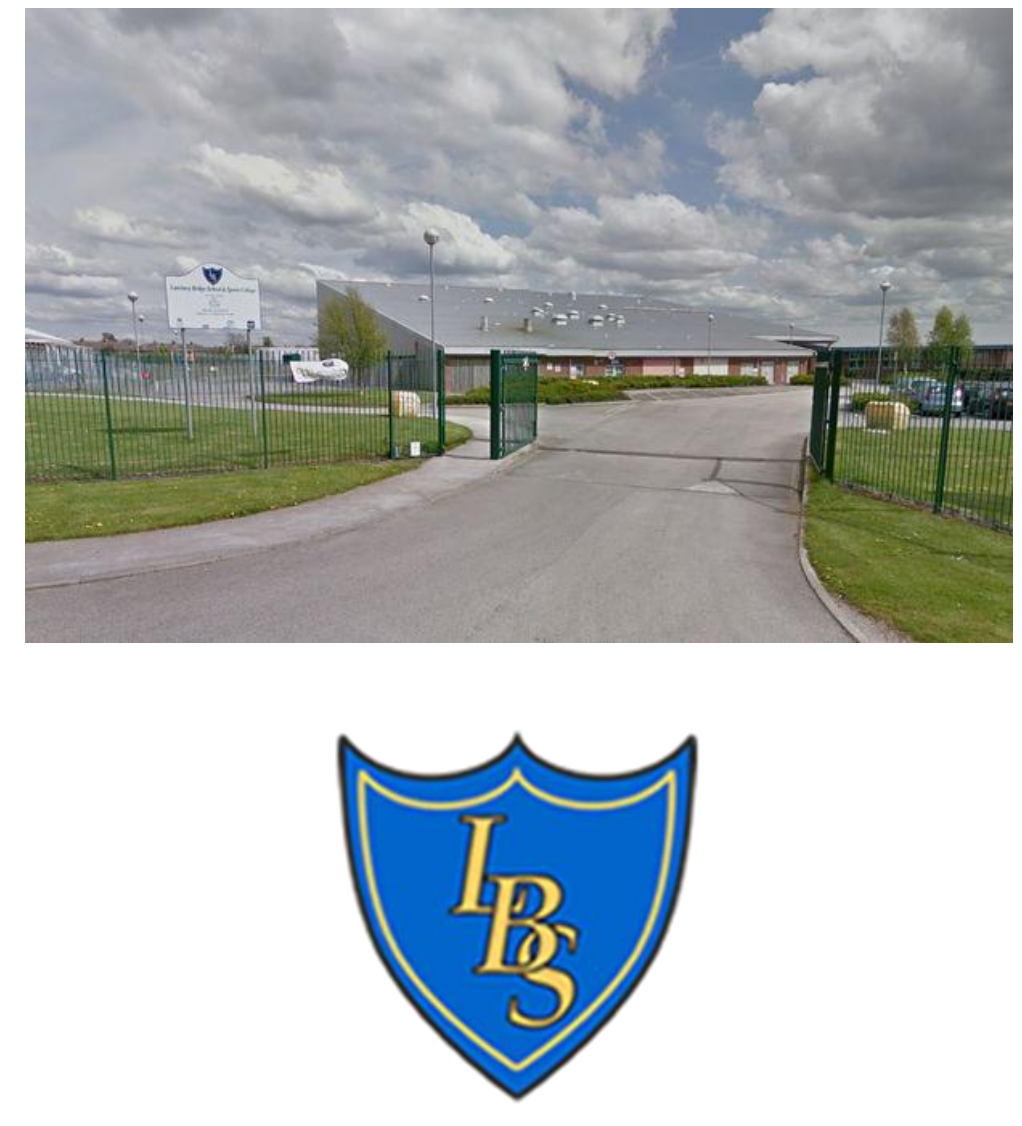


\section{What is $\mathrm{LEGO}^{\circledR}$-based therapy?}

LEGO ${ }^{\circledR}$-based therapy takes a naturalistic approach to the development of social communication skills (LeGoff, 2004; LeGoff et al., 2014)

It uses play to develop social communication by creating opportunities for interaction collaborative play therapy

Group members take on roles as they communicate and work together with peers following the social rules of communication to collaboratively build LEGO® ${ }^{\circledR}$ sets

It uses children's interests to promote the development of social, communication and play skills (Attwood, 1998)

Can be linked to Baron Cohen's Empathising-Systemising model (Baron-Cohen et al, 2005) and social constructivism

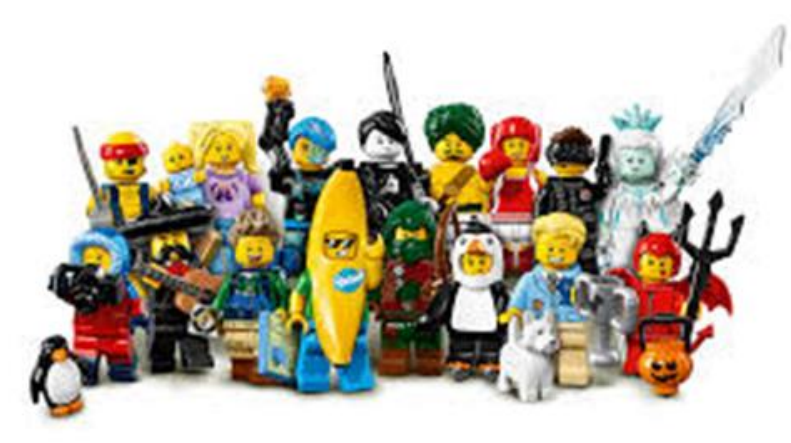




\section{LEGO ${ }^{\circledR}$-based therapy uses}

Can help to develop a child/young person's ability to:

- Initiate conversations with peers

- Sustain interactions with peers for an increased length of time

- Problem-solve whilst building a specified model in groups of three

- Practice social skills such as turn taking, joint attention, sharing, joint problem-solving and listening

- Share goals and mutual purpose with peers

Primarily used with verbal young people with Autism Spectrum Condition (ASC) (LeGoff, 2004; LeGoff et al., 2014) 


\section{Why a potential use with AAC Users?}

18.9\% of UK AAC users have a diagnosis of ASC (Enderby et al., 2013)

Social communication and interaction skills are often highlighted as an area of challenge for many AAC users (Light and McNaughton, 2014)

Andrews et al. (2012) highlighted potential benefits to verbal communication such as vocabulary development

Anecdotal observations have been made by many speech and language therapists of the benefits to AAC users in a range of areas of communication development

Potential to help develop areas of communicative competency 


\section{Communicative Competency}

"A dynamic interpersonal construct based on functionality of communication; adequacy of communication; and sufficiency of knowledge, judgement and skills"

- Light (1987), Light \& McNaughton (2014)

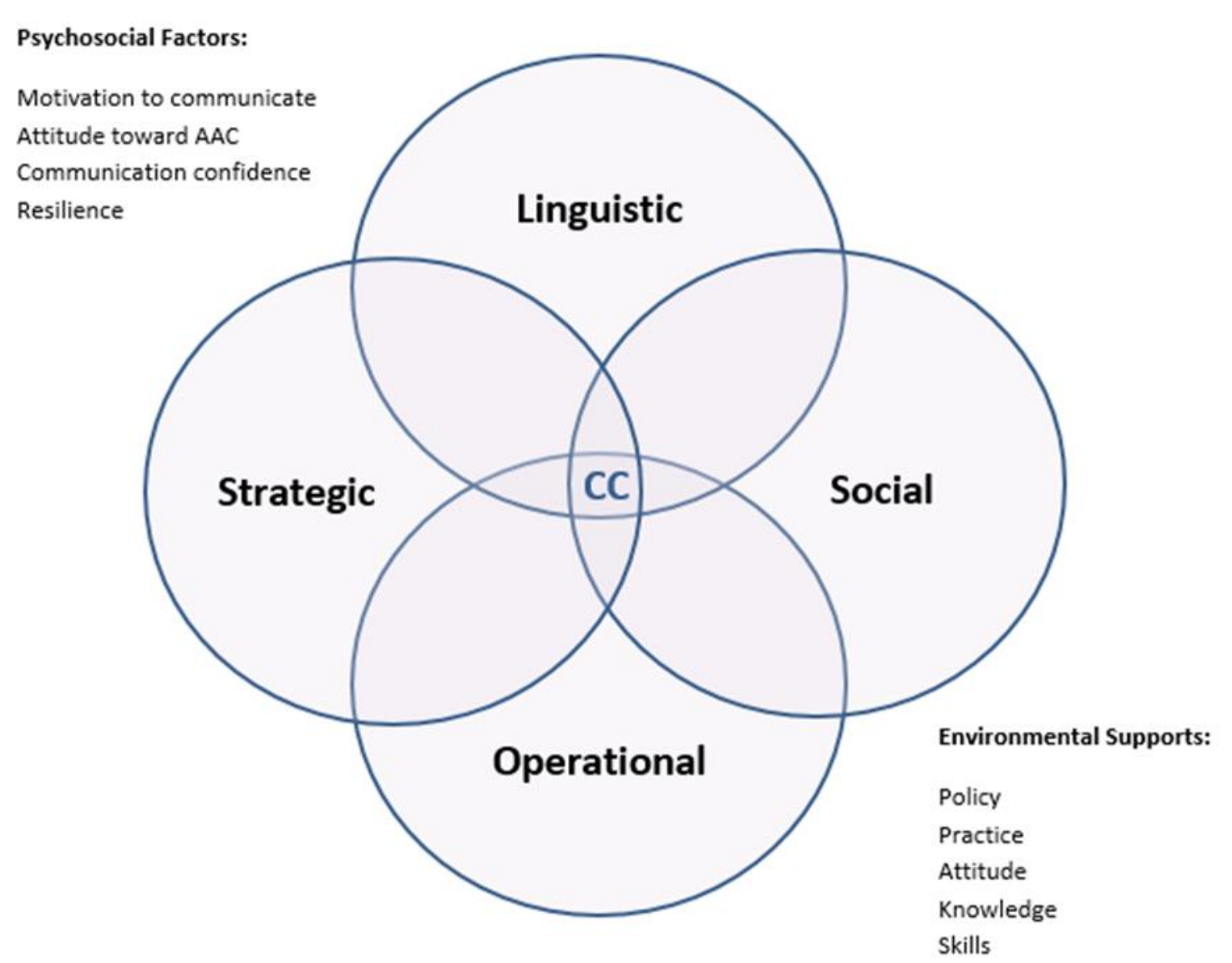




\section{Links to LEGO ${ }^{\circledR}$-based therapy}

The structure of the group and roles within it provides children with the opportunity to develop single or multiple areas of competency

1. Engineer

Describes the instructions (largely expressive)

2. Supplier

Finds the right pieces (largely receptive)

3. Builder

Puts the pieces together (largely receptive)

4. Inspector

Makes sure that the team is working effectively (largely expressive) 


\section{Gamification}

LEGO ${ }^{\circledR}$-based therapy can be viewed as approach involving many gamification techniques.

Gamification provides a balance between the development of social interaction and gaming (Mosley and Whitton, 2014)

Adults within $\mathrm{LEGO}^{\circledR}$-based therapy act as facilitators; drawing influence from social constructivism with the adult's role less of a teacher and more a part of a co-operative learning process between the learner, their facilitator and their environment (Palincsar, 1998)

Learners are able to demonstrate their capabilities and draw their own conclusions (Rhodes and Bellamy, 1999; Brownstein, 2001)

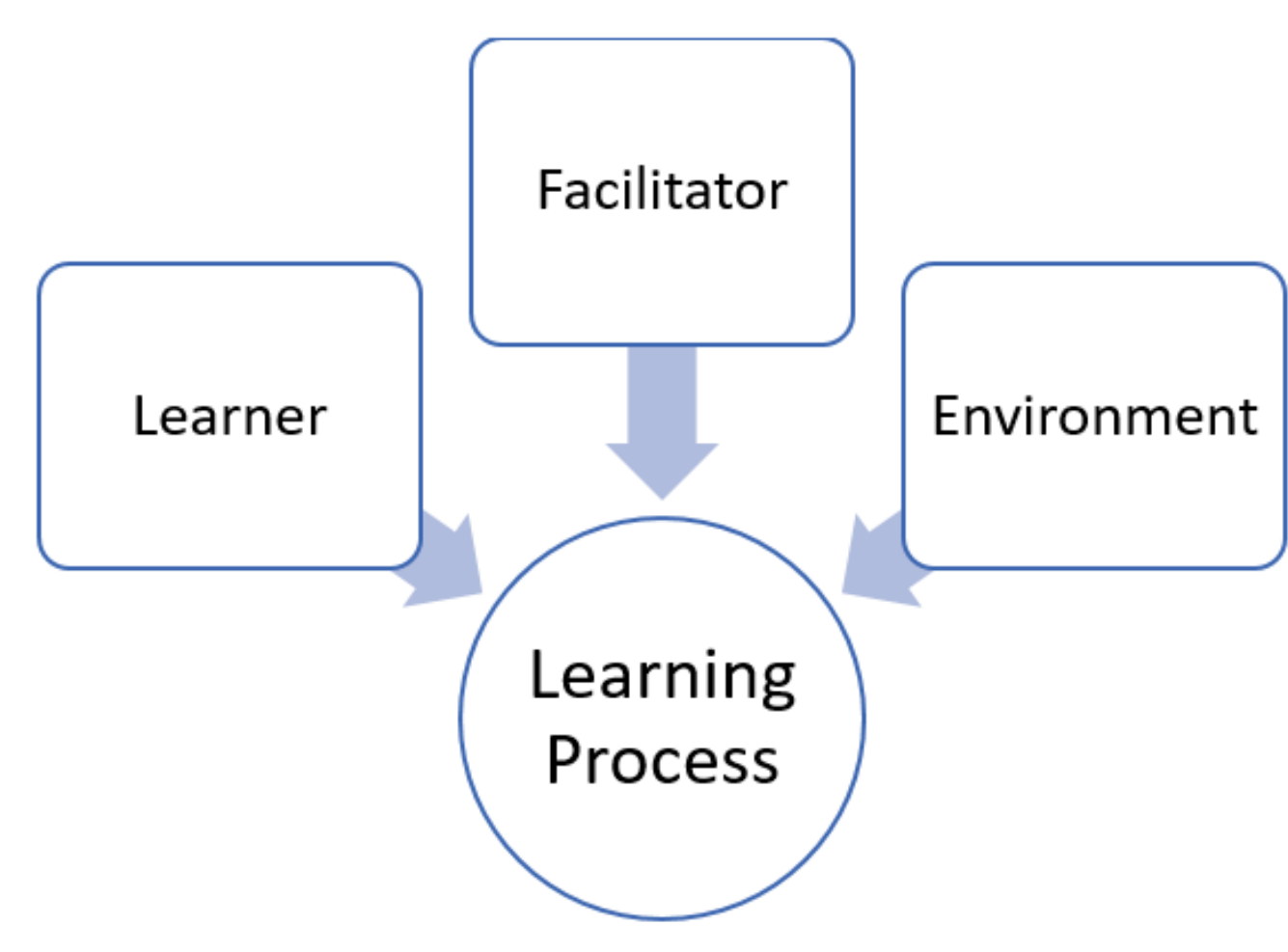

Diagram based on Palincsar (1998) 


\section{Gamification}

LEGO ${ }^{\circledR}$-based therapy is one of the only naturalistic social competency interventions that has succeeded in participants generalising their learnt skills to other environments (LeGoff, 2004)

Moseley and Whitton (2014) suggest that if created with a balance between gaming and educational content, games can develop experiential learning and generalisation of skills to other environments. This occurs by learners testing skills that they have acquired (Hopkins and Roberts, 2015)

Moseley and Whitton also suggest that such games can promote "key generalisable skills such as communication, negotiation and teamwork" (2012:12) 


\section{Case study outcomes}

The initial findings from a series of case studies highlight the potential benefits of using a gamification approach featuring adapted LEGO ${ }^{\circledR}$-based therapy, to develop single or multiple communication competencies in young AAC users with developmental disabilities

The findings also indicate the successful adaption of LeGoff's (2004) original LEGO ${ }^{\oplus}$-based therapy design, as a therapeutic intervention to enhance single and multiple communicative competences of young AAC users

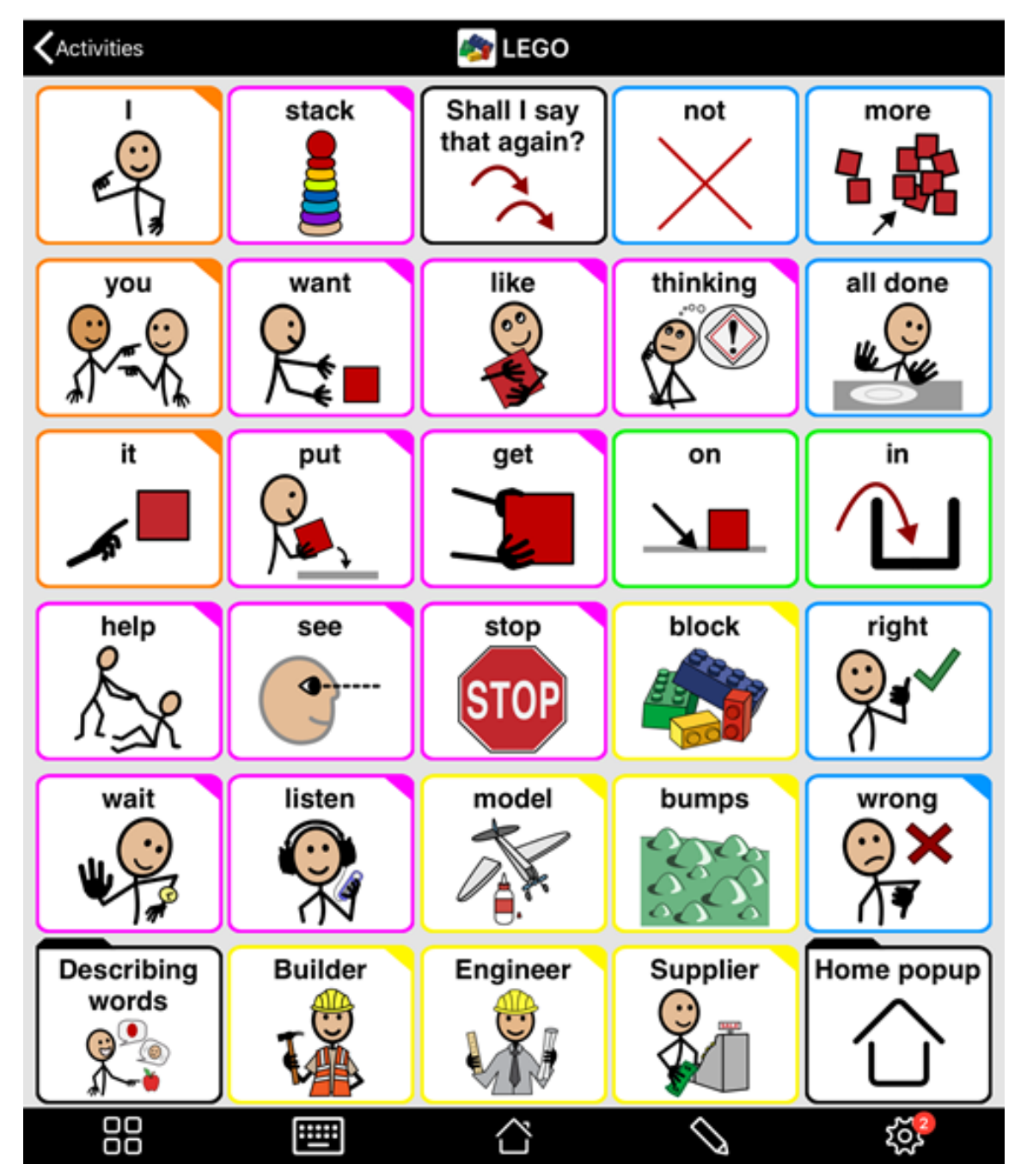




\section{Further case study outcomes}

The case studies provide insights into the development of communicative competencies (linguistic, operational, social, strategic) coupled with the influence of psychosocial factors and environmental supports

The project highlighted the importance of recognising and responding to linguistic, operational, social and strategic challenges faced by children using AAC devices

during therapeutic intervention

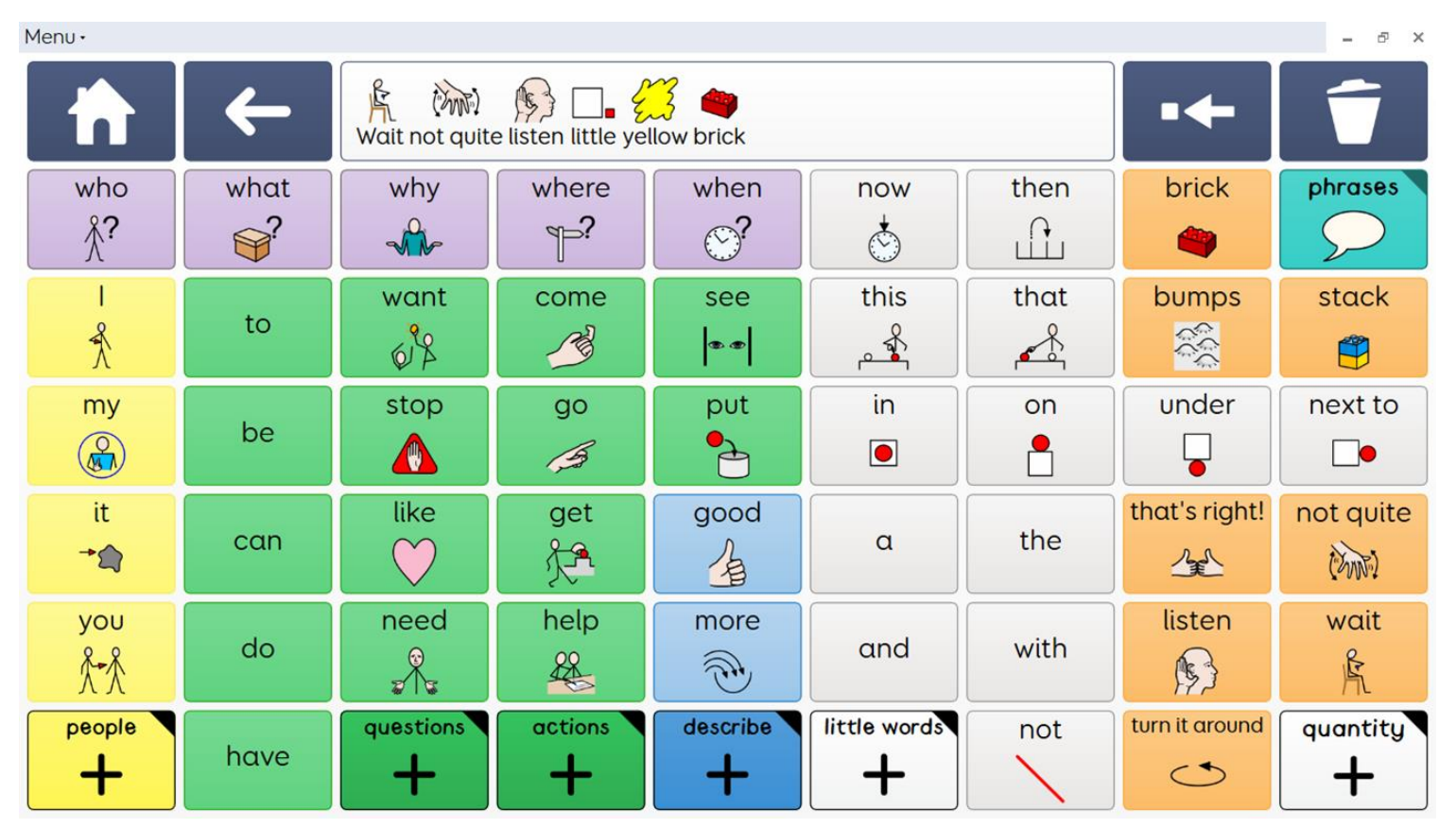

The use of adapted LEGO ${ }^{\circledR}$-based therapy with young AAC users is not without challenges, but these are not insurmountable 


\section{Considerations}

Adapted $L E G O{ }^{\circledR}$-based therapy has been explored in this presentation:

- There are significant differences in the role of adult facilitators with an AAC client group; facilitators seem to be more heavily relied upon than in an ASD group and effective communicative partners are vital (Blackstone and Hunt Berg, 2012

- All adult facilitators require training and support and the success of the intervention can reply heavily upon the strength of the supporting staff members

- Some sessions were quite short in duration due to the fatigue encountered by many of the users; especially those using eye gaze access methods of access

- Time requirements for personalisation of resources - clinical costings

- Potential preparatory sessions required to develop pre-requisite skills for accessing a group e.g. folder navigation skills, use of social language such as "I don't understand" 


\section{References}

Attwood, T. (1998) Asperger's. London: Jessica Kingsley Publishers.

Baron-Cohen, S., Wheelwright, S., Lawson, J., Griffin, R., Ashwin, C., Billington, J. and Chakrabarti, B. (2005) Empathizing and systemizing in autism spectrum conditions. In: Volkmar, F., Klin, A. and Paul, R. (Eds). Handbook of autism and pervasive development disorders. $3^{\text {rd }}$ edition. Chichester: John Wiley \& Sons.

Brownstein, B. (2001).'Collaboration: the foundation of learning in the future'. Education, 122(2) pp. 240.

Enderby, P., Judge, S., Creer, S., and John, A. (2013). 'Beyond the Anecdote: Examining the Need for, and Provision of, AAC in the United Kingdom.' Research Report, Communication Matters. [Online] [Accessed on $28^{\text {th }}$ March 2017]

http://eprints.whiterose.ac.uk/76406/1/2013_AAC_Evidence_Base_Beyond_the_Anecdote.pdf

Hopkins, I. and Roberts, D. (2015). 'Chocolate-covered Broccoli'? Games and the Teaching of Literature'. Changing English, 22(2) pp. 222-236.

LeGoff, D. B. (2004). 'Use of Lego@ as a Therapeutic Medium for Improving Social Competence.' Journal of Autism and Developmental Disorders, 34(5) pp. 557-571.

LeGoff, D. B. and Sherman, M. (2006). 'Long-term outcome of social skills intervention based on interactive LEGO@ play.' Autism, 10(4) pp. 317-

329.

LeGoff, D. B., Gómez de la Cuesta, Krauss, G. W., Baron-Cohen, S. (2014). LEGO®-BasedTherapy. London: Jessica Kingsley Publishers.

Light, J. (1989) 'Toward a Definition of Communicative Competence for Individuals using Augmentative and Alternative Communication

Systems.' Augmentative and Alternative Communication, 5(2) pp. 137-144.

Light, J. C. and McNaughton, D. (2012). 'The changing face of augmentative and alternative communication: past, present, and future challenges.' Augmentative and Alternative Communication, 28(4) pp. 197-204.

Light, J. C. and McNaughton, D. (2014). 'Communicative Competence for Individuals who require Augmentative and Alternative

Communication: A New Definition for a New Era of Communication?' Augmentative and Alternative Communication, 30(1) pp. 1-18.

Lindsay, S., Hounsell, K. G., Cassiani, C. (2017). 'A scoping review of the role of LEGO ${ }^{\circledR}$ therapy for improving inclusion and social skills among children and youth with autism.' Disability and Health Journal, 10, pp. 173-182.

Moseley and Whitton (2012) in Moseley, A., and Whitton (Eds.) (2012). Using Games to Enhance Learning and Teaching: A Beginner's

Guide. London: Routledge.

Mosley, A. and Whitton, N. (Eds.) (2014) New Traditional Games for Learning: A Case Book. London: Routledge.

Owens, G., Granader, Y., Humphrey, A and Baron-Cohen, S. (2008). 'LEGO@ Therapy and the Social Use of Language Programme: An

Evaluation of Two Social Skills Interventions for Children with High Functioning Autism and Asperger Syndrome.' Journal of Autism and Developmental Disorders, 38, pp1944-1957.

Palincsar, A. S. (1998). 'Social constructivist perspectives on teaching and learning', Annual Review of Psychology, 49(1), pp. 345-375. Rhodes, L. K. and Bellamy, G. T. (1999). 'Choices and Consequences in the Renewal of Teacher Education'. Journal of Teacher Education, 50 pp. 17-26. 


\title{
Thank you for listening - any questions?
}

Please feel free to contact me for any further information

\author{
Nicola Dutton
}

nicola.j.dutton2@stu.mmu.ac.uk

$$
07564055368
$$

